\title{
Effect of Synertox ${ }^{\circledR}$ on broiler health and performance during aflatoxicosis
}

\author{
A.M. Shareef and E.K.S. Omar \\ Department of Veterinary Public Health, College of Veterinary Medicine, University of Mosul, Mosul, Iraq
}

\begin{abstract}
Eighty, one-day-old commercial male broiler chicks (Ross 308), were distributed to four dietary treatments with two replicates of 10 chicks each, to study the effect of Synertox ${ }^{\circledR}$ on broiler performance during aflatoxicosis. Birds were reared for 42 days. All birds were fed on diet with or without aflatoxin (AF) in feed, and with or without Synertox (ST) (enzymes, organic acids and yeast extract) in water. The treatments were as follow: T1 (0 ppm AF and no ST); T2 (2.5 ppm AF and no $\mathrm{ST})$; T3 (0 ppm AF and $0.5 \mathrm{ml} / 1 \mathrm{ST})$; T4 (2.5 ppm AF and $0.5 \mathrm{ml} / 1 \mathrm{ST})$. Body weights and feed intake were recorded weekly. At 42 of bird's age, five birds were randomly selected for estimation of antibody titres against Newcastle disease (ND; for calculation of the relative weight of bursa of Fabricius, thymus and spleen as well as for scoring liver and kidney lesions. The results show that the total body weight gain through 42 days of rearing period that the gain was highest in T3. In the second order was the weight of the control group (T1), while in the third order was T4. The worst body weight gain was reported in $\mathrm{T} 2$, in which chicks fed AF. The same picture in body weight gain was obtained with feed consumption and feed conversion ratio. $\mathrm{AF}$ had a significant negative effect on the liver parenchyma of broiler chicks in treatment 2 , by changing liver colour from mahogany to enlarged muddy or even to yellowish discolouration, with friable consistency with sub capsular haemorrhages. The addition of Synertox ${ }^{\circledR}$ was effective in restoring the normal red brown liver colour. Kidney were also affected by feeding AF (T2). They were enlarged, swollen and pale in colour. All lymphoid organs tested, thymus, bursa of Fabricius and spleen were negatively affected by feeding AF in broilers at 42 days of age. Synertox ${ }^{\circledR}$ was effective in counteracting the negative effect of AF on relative bursal weight, thymus and spleen relative weights. Aflatoxin had detrimental negative effect on the ND ELISA mean antibody titre. A significant restoring of ND antibody titre to those of control group (T1) was recorded by addition of Synertox ${ }^{\circledR}$ to the drinking water of broilers in (T4) compared with the AF fed T2 group. From the studied parameters it could be concluded that Synertox ${ }^{\circledR}$ could be used in counteracting the negative effects of AF on health and performance of broiler chicks.
\end{abstract}

Keywords: Aflatoxin; Synertox; Newcastle disease; Broilers.

Available online at http://www.vetmedmosul.org/ijvs

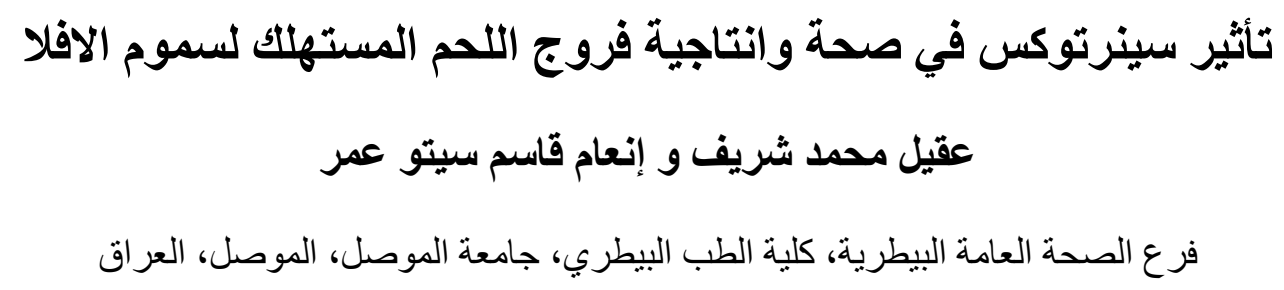

الخلاصة

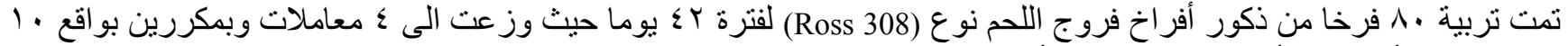

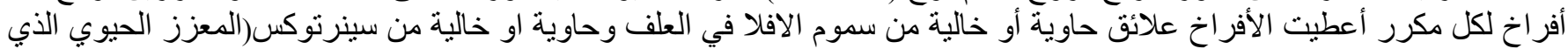

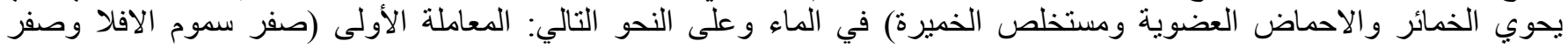

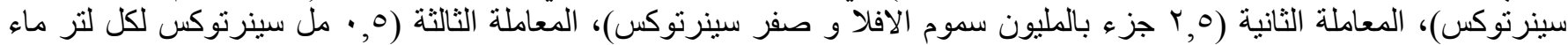

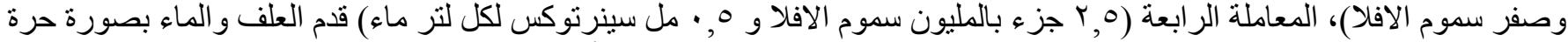

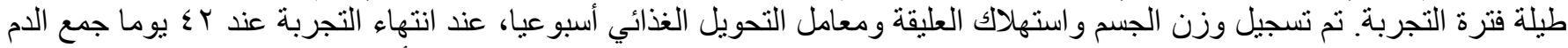

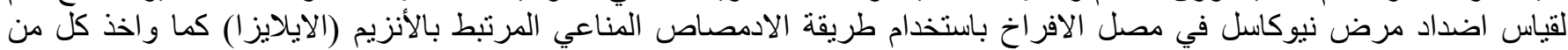
الطحال وجر اب غدة فابريشيا وغدة التوثة لحساب وز انهم النسبية بالنسبة لوزن جسم الطائر الحي وكذلك تم حساب تدرج الإنية الآفة لكل من 


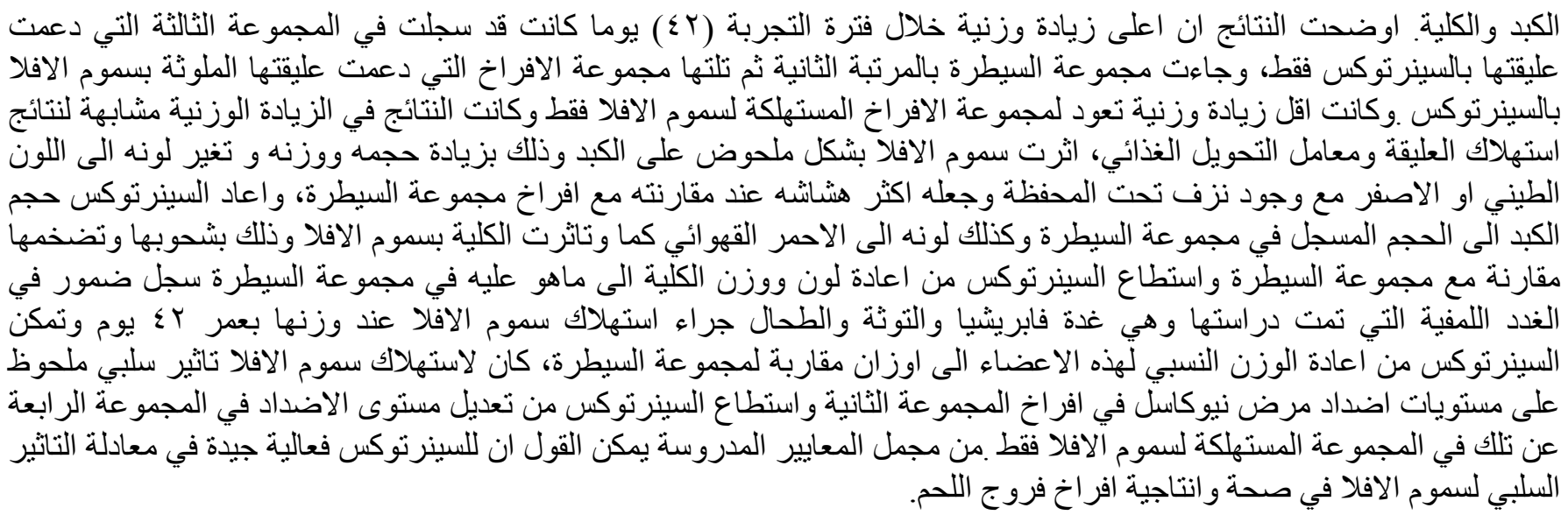

\section{Introduction}

Aflatoxins (AF), the toxic secondary metabolites produced by Aspergillus flavus and Aspergillus parasiticus, are a major concern in the poultry production. AF metabolites are stable and fairly resistant compounds to degradation. These metabolites are usually produced during the growth of the Aspergillus flavus, Aspergillus parasitcus and Aspergillus nominus on certain foods and feedstuffs under favourable conditions of moisture, temperature and aeration (1). Their toxicity depends on several factors including its concentration, the duration of exposure, the species, sex, age, and health status of animals. Contamination of AF in feed causes aflatoxicosis in poultry that is characterised by reduced feed intake, decreased weight gain, poor feed utilization, increased susceptibility to environmental and microbial stresses, and increased mortality (2). AF can also cause productive deterioration which is associated with changes in and impaired immunity, which is able to enhance susceptibility to some environmental and infectious agents (3). Severe economic losses have been reported in the poultry industry due to aflatoxicosis (4). Ultimately, the transmission of AF and its metabolites from feed to animal edible tissues and products, such as liver and eggs, becomes a potential hazard for human health. With increasing knowledge and awareness of AF as a potent source of health hazards to both man and farm animals, producers, researchers and government organizations are making great effort to develop effective preventive management and decontamination technologies to minimise the toxic effects of $\mathrm{AF}$ content in foods and feedstuffs.

Appropriate pre and post-harvest contamination can be reduced by using appropriate agricultural practices. However, the contamination is often unavoidable and still remains a serious problem associated with many important agricultural commodities, which emphasizes the need for a suitable process to inactivate the toxin. Besides the preventive management, several approaches have been employed including physical, chemical biological treatments and solvent extraction to detoxify $\mathrm{AF}$ in contaminated feeds and feedstuffs (5). The increasing number of reports on detoxification of AF in poultry feed using different techniques has given rise to a demand for practical and economical detoxification procedure. Since the beginning of 1990s, the adsorbent-based studies have been reported to be effective in removing $\mathrm{AF}$ from contaminated feed and minimise the toxicity of AF in poultry. Among several adsorbents commercially available in the market, Zeolites (6), bentonites (7) and clinoptilolite (CLI), (8), were preferred because of their high binding capacities for $\mathrm{AF}$ and their reducing effect on AFabsorption from the gastrointestinal tract.

Although several mycotoxin detoxitoxifying or adsorbing techniques have been used by the addition of different adsorbents in feed, however, limited information is available on an alternative strategy of aflatoxin detoxification, like dietary acids (9), live microfloral additives (10) and mannanoligosaccharides (11) in diets of chickens may help digestion by inhibiting bacteria growth and regulate $\mathrm{pH}$ value in intestines when incorporated into diet formulations. There are many commercial products are used for detoxification including mycotoxin-binding agents holds promise for using contaminated feeds (12). Esterified- glucomannan, a cell wall derivative of Saccharomyces cerevisiae, was protective against aflatoxin B1 and ochratoxin. Lactobaccillus cultures prevented absorption of aflatoxin from intestine (13). This study was carried out as a field trial to evaluate preventive value of detoxifying commercial product mixture including soluble enzymes, yeast extract and organic acids (Synertox) in Ross broilers where health and performance parameters were determined during a period of 6 weeks to evaluate the ameliorating effect of Synertox in broilers during Aflatoxicosis., i.e., by adding Synertox ${ }^{\circledR}$ to water (14). 
Synertox ${ }^{\circledR}$ contains an excellent cocktail content of organic acids and their salts, essential micronutrients and the extract of L- form microorganisms, which plays an important role as a chelating agent in the sequestration of the mycotoxin through the gastrointestinal tract, preventing them from absorption, and so help in getting rid of these toxins outside the body.

For understanding the effect of Synertox on aflatoxin detoxification, a study was conducted to investigate its effect on broiler health and performance during aflatoxicosis.

\section{Materials and methods}

\section{Birds and diet}

Eighty, one-day-old commercial male broiler chicks (ROSS 308), were randomly distributed to four dietary treatments with two replicates of 10 chicks each. During the 42 days, all birds were fed on diet with or without aflatoxin (AF) and Synertox (ST). The ingredient composition of the basal diet is based on NRC (1994) (15), presented in Table 1. Feed and water was available on ad libitum basis. All the birds were vaccinated against Newcastle Disease (N.D.), in drinking water with $\mathrm{B} 1$ at 1-day; with oil based vaccine (intra muscular) at day 8 and by Lasota strain at 21 days of age.

\section{Experimental design}

The experimental design consists of four dietary treatments; T1 (0 ppm AF and no ST); T2 (2.5 ppm AF and no ST); T3 (0 ppm AF and $0.5 \mathrm{ml} / 1 \mathrm{ST})$; $\mathrm{T} 4$ (2.5 ppm AF and $0.5 \mathrm{ml} / 1 \mathrm{ST}$ ).

\section{Aflatoxin production and analysis}

Aflatoxins were produced by the inoculation of fungus on rice as described by (16).

Aflatoxin containing rice was quantitatively evaluated using thin layer chromatography technique according to (17), using the formula:

$\mathrm{DM} \times 10^{6}$

$$
\mathrm{AF} \mathrm{mg} / \mathrm{kg}=
$$

The AF containing rice was mixed in feed according to the calculation to get the desirable level of aflatoxin, 2.5 $\mathrm{ppm})$ in the feed. The prepared experimental diets were analysed again using TLC technique to confirm the AF levels.

\section{Detoxification of AF}

A commercially available Synertox ${ }^{\circledR}$ plus (NAFA Agriculture), was added in to the water at the recommended dose rate of $0.5 \mathrm{ml} / \mathrm{l}$ of drinking water (Treatment 2 and 4).
Table 1. Ingredient and nutrient composition of basal starter and grower diet of broilers.

\begin{tabular}{lcc}
\hline Ingredients & Starter\% & Grower\% \\
\hline Maize & 43.5 & 44.3 \\
Wheat & 25.8 & 1.8 \\
Soybean meal & 25.8 & 23.8 \\
Protein concentrate & 10 & 10 \\
Salt (Nacl) & 0.3 & 0.3 \\
Di-calcium phosphate & 0.4 & 0.4 \\
Sunflower oil & 2 & 3.4 \\
\hline Summation & 100 & 100 \\
\hline Calculated nutrients composition & & \\
\hline Crude protein (\%) & 22.11 & 21.20 \\
ME (cal/kg) & 3005.5 & 3105.6 \\
Percent of ME/ crude protein & 136 & 146.5 \\
Lysine (\%) & 1.14 & 1.08 \\
Methionine and cystine (\%) & 0.78 & 0.75 \\
Calcium (\%) & 1.03 & 1.03 \\
Phosphorous available (\%) & 0.47 & 0.47 \\
Crude fiber (\%) & 3.603 & 3.466 \\
Fat $\%$ ) & 5.23 & 6.64 \\
\hline
\end{tabular}

\section{Sampling}

Body weights and feed intake per pen was recorded weekly. At 42 of bird's age, five birds per replicate were randomly selected for estimation of antibody titres against Newcastle disease (ND). The blood samples $(3 \mathrm{ml}$ ) were collected from wing vein. The blood serum was separated and analysed by Enzyme linked immune-sorbent assay (ELISA) described by (18). After blood collection, birds were humanely killed and bursa of Fabricius, thymus and spleen were removed and weighed. Score gross lesion of liver and kidney were recorded. For liver, score lesion (03): 0: no lesion; 1: congestion; 2 : fatty change in liver with muddy or yellowish discolouration; 3: liver yellowish discolouration with sub capsular haemorrhage.. For kidney, score lesion (0-3): 0: no lesion; 1: congestion; 2: paleness discolouration; 3: Paleness with sub capsular haemorrhage.

\section{Statistical analysis}

The results (pen means) were subjected to analysis of variance (ANOVA). Means were subjected to Duncan's test and statistical significance was accepted at $\mathrm{P}<0.05(19)$.

\section{Results}

\section{Growth performance}

The body weight of broiler chicks through 5 weeks of experimental period show significant differences between experimental treatments, Figure 1). There was a significant reduction in body weight in $\mathrm{T} 2$ compared with $\mathrm{T} 1$. The reduction was noticed from the first week and persist through the following five weeks of rearing broilers. 
Addition of Synertox ${ }^{\circledR}$ in T4, was effective in restoring the body weight to that of control one, since there was a significant difference between $\mathrm{T} 4$ and $\mathrm{T} 2$.

The total body weight gain through 42 days of rearing period are representing in Table (1). From table it is evident that the gain was highest in T3. In the second order was the weight of the control group (T1), while in the third order was T4. The last two treatments (T1 and T4) were not differ significantly in their body weight gain. The worst body weight gain was reported in $\mathrm{T} 2$.

The same picture in body weight gain was obtained with feed consumption. A reflection of feed consumption and body weight gain in the four treatment groups was noticed in the results of feed conversion ratio. The lowest feed consumption and feed conversion ratio were reported in T2. Amending Aflatoxin contaminated feed with Synertox ${ }^{\circledR}$ in drinking water was effective in counteracting the negative effect of AF on growth performance parameters of broilers. Addition of Synertox ${ }^{\circledR}$ alone to the drinking water, T3) had not negative effect on the studied growth performance parameters.

\section{Liver and kidney score lesions}

The effect of AF and Synertox ${ }^{\circledR}$ on liver and kidney lesion scores in broilers at 42 days of age are presented in table (2). It is evident that AF had a significant negative effect on the liver parenchyma of broiler chicks in treatment 2 , when compared with that of control group (T1), by changing liver colour from mahogany (Figure 2), to that which characterised by enlarged muddy or even to yellowish discolouration, with friable consistency and sub capsular haemorrhages, Figure 3). The addition of Synertox ${ }^{\circledR}$ to the drinking water of broilers in treatment 4 , was effective in restoring the normal red brown liver colour to that of chicks in treatment 1 (Figure 4). Kidney was also affected by feeding AF (T2), in a significant manner when compared with all other treatment groups (T1, T3 and T4). They were enlarged, swollen and pale in colour.

\section{Relative lymphoid organs weight}

All lymphoid organs, thymus, bursa of Fabricius and spleen were negatively affected by feeding AF in broilers at 42 days of age (Table 3 ). Thymus bursal relative weights were significantly reduced in (T2), compared with control treatment group (T1). Amending drinking water with the detoxifying Synertox ${ }^{\circledR}$ in treatment 4 was effectively ameliorate the negative AF effect on these organs, compared with T2. Opposite picture was noticed with spleen, since AF had a significant increase in the relative weight of the spleen in T2, compared with (T1, T3 and T4). Detoxifying AF by addition of Synertox to T4 broilers was effective in returning spleen weight to that of control one.

\section{Antibody titre}

The means of antibody titre (HA) against Newcastle disease (ND) showed significant $(\mathrm{P}>0.05)$ difference between treatments when analysed at 42 day of the trial (Figures 5 and 6). Aflatoxin had detrimental negative effect on the significant $(\mathrm{P}<0.05)$ reduction of ND ELISA mean antibody titre of 2441.2 with \% CV of 74.92 , compared with the control treatment (T1), which had ND titre of 5508.60 with \% CV of 36.96. A significant restoring of ND antibody titre to those of control group (T1) was recorded by addition of Synertox ${ }^{\circledR}$ to the drinking water of broilers in (T4) to be 5345 with \% CV of 34.42, compared with the $\mathrm{AF}$ fed $\mathrm{T} 2$ group.

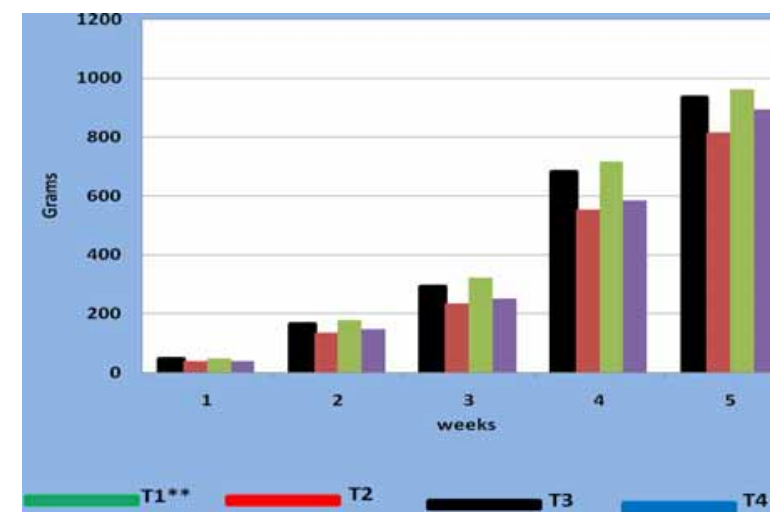

Figure 1: Effect of Aflatoxin and Synertox ${ }^{\circledR}$ on Weekly body weight of broiler chicks*. *Mean body weight for 10 birds. **T1 (0 ppm AF and no ST); T2 (2.5 ppm AF and no $\mathrm{ST})$; T3 (0 ppm AF and $0.5 \mathrm{ml} / 1 \mathrm{ST})$; T4 (2.5 ppm AF and $0.5 \mathrm{ml} / \mathrm{l} \mathrm{ST})$.

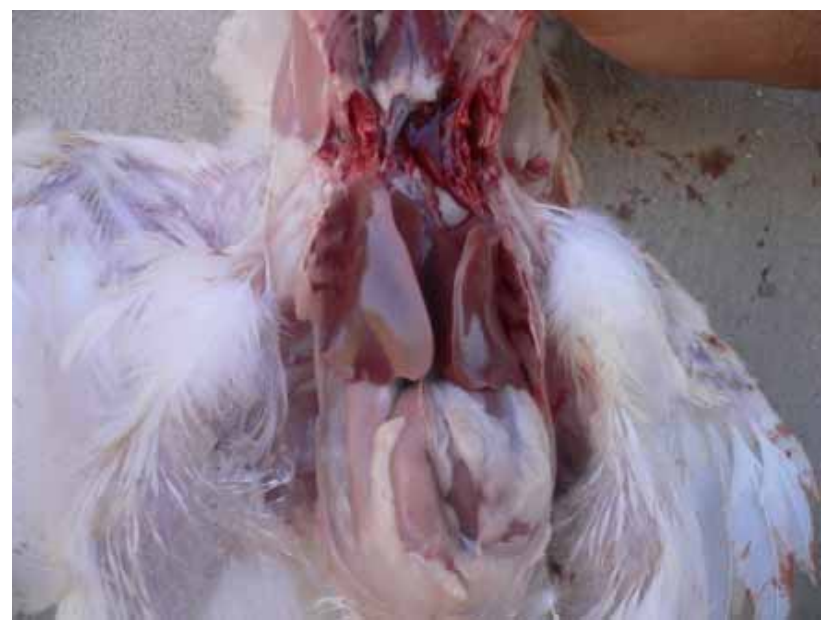

Figure 2: Liver of broiler in treatment 1 , fed no Aflatoxin or Synertox ${ }^{\circledR}$. Normal, red or mahogany liver of broilers at 42 days of age. 


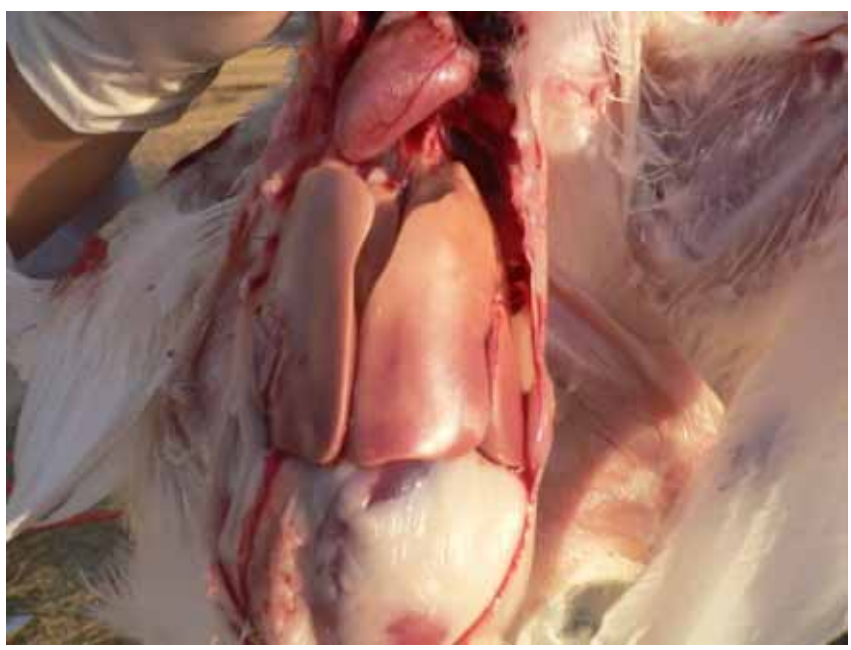

Figure 3: Liver of broiler in treatment 2, fed Aflatoxin. Extreme pale, yellowish greasy liver (fatty change), large and fragile of broilers at 42 days of age.

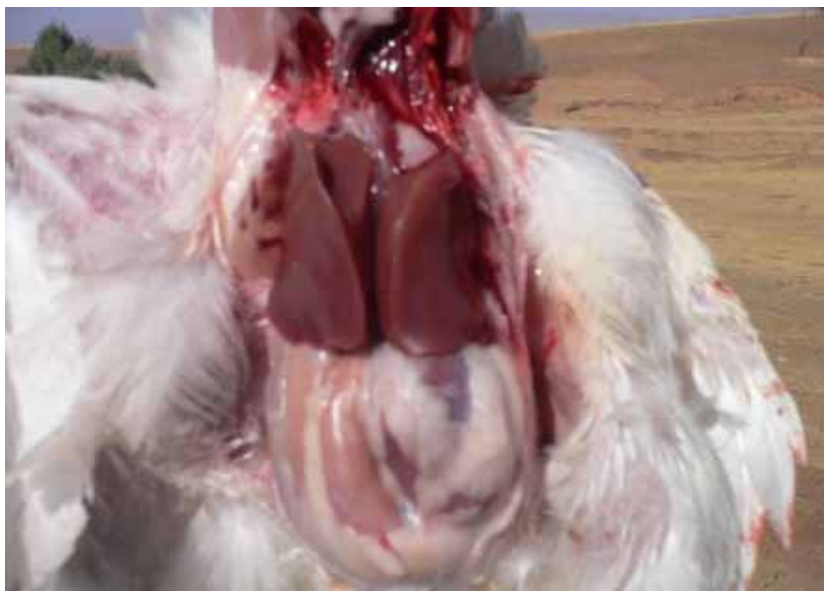

Figure 4: Liver of broiler in treatment 4, fed Aflatoxin and Synertox ${ }^{\circledR}$. Normal, red brown liver of broilers at 42 days of age.

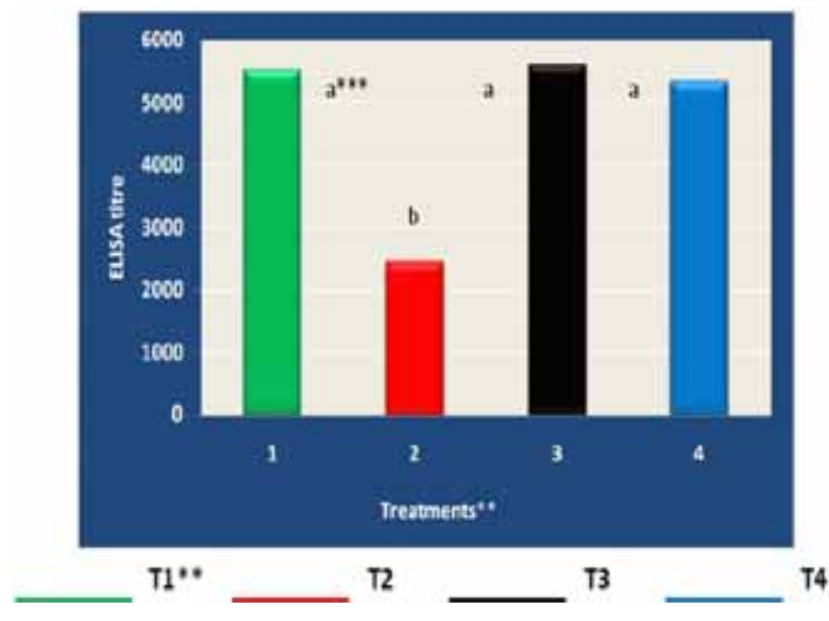

Figure 5: Newcastle antibody titre of broiler chicks fed no Aflatoxin and Synertox ${ }^{\circledR}$ at 42 days of age*.

*Mean ELISA titre for 5 birds, **T1 (0 ppm AF and no $\mathrm{ST})$; T2 (2.5 ppm AF and no ST); T3 (0 ppm AF and 0.5 $\mathrm{ml} / 1 \mathrm{ST}) ; \mathrm{T} 4$ (2.5 ppm AF and $0.5 \mathrm{ml} / \mathrm{l} \mathrm{ST})$, ***Means with same superscripts do not differ from each other $(\mathrm{P}>0.05)$.

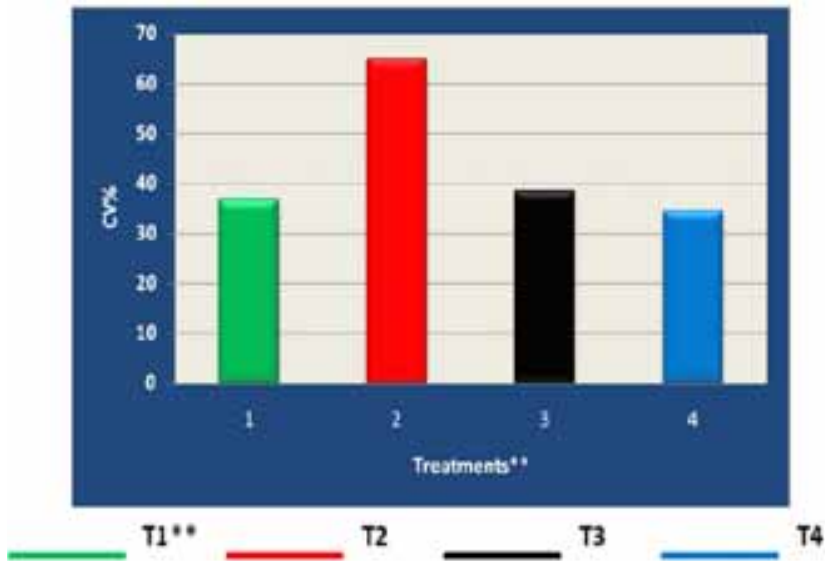

Figure 6: Newcastle CV\% of antibody titre in broiler chicks fed no Aflatoxin and Synertox ${ }^{\circledR}$ at 42 days of age*.

$*$ Mean ELISA titre for 5 birds, ${ }^{* *} \mathrm{~T} 1(0 \mathrm{ppm}$ AF and no $\mathrm{ST}) ; \mathrm{T} 2$ (2.5 ppm AF and no ST); T3 (0 ppm AF and 0.5 $\mathrm{ml} / \mathrm{l} \mathrm{ST}) ; \mathrm{T} 4(2.5 \mathrm{ppm} \mathrm{AF}$ and $0.5 \mathrm{ml} / \mathrm{l} \mathrm{ST})$.

Table 1: Effect of Aflatoxin and Synertox ${ }^{\circledR}$ on growth performance of broiler chicks at 42 days of age*.

\begin{tabular}{lccccc}
\hline Treatments & AF (in feed) $(\mathrm{ppm})$ & Synertox ${ }^{\circledR}($ in water) $(\mathrm{ml} / \mathrm{L})$ & Weight Gain $(\mathrm{g})$ & Feed Intake $(\mathrm{g})$ & FCR $(\mathrm{g} / \mathrm{g})$ \\
\hline T1** & 0 & 0 & $933.2 \pm 14.3 \mathrm{bc}$ & $2141.9 \pm 51.8 \mathrm{bc}$ & $2.29 \pm 0.02 \mathrm{a}$ \\
$\mathrm{T} 2$ & 2.5 & 0 & $816.1 \pm 28.5 \mathrm{e}$ & $2138.5 \pm 56.7 \mathrm{~d}$ & $2.62 \pm 0.04 \mathrm{c}$ \\
$\mathrm{T} 3$ & 0 & 0.5 & $961 \pm 19.1 \mathrm{a} * * *$ & $2203.7 \pm 56.8 \mathrm{a}$ & $2.29 \pm 0.02 \mathrm{a}$ \\
$\mathrm{T} 4$ & 2.5 & 0.5 & $894.5 \pm 37.4 \mathrm{bcd}$ & $2164.6 \pm 88.6 \mathrm{bc}$ & $2.41 \pm 0.04 \mathrm{ab}$ \\
\hline
\end{tabular}

*Mean \pm SE for 10 birds, ${ }^{* * T} 1$ (0 ppm AF and no ST); T2 (2.5 ppm AF and no ST); T3 (0 ppm AF and 0.5 ml/1 ST); T4 (2.5 ppm AF and $0.5 \mathrm{ml} / 1 \mathrm{ST}),{ }^{* * *}$ Means with same superscripts within a column do not differ from each other $(\mathrm{P}>0.05)$. 
Table 2: Effect of Synertox ${ }^{\circledR} \mathrm{ml} / \mathrm{L}$ Synertox ${ }^{\circledR}(0.5 \mathrm{ml} / \mathrm{L}$ of water) on gross score lesions for broiler chicks fed on a diet containing $2.5 \mathrm{ppm}$ aflatoxin (AF) between 1 and 42 days of age.

\begin{tabular}{lcccccccccc}
\hline & \multicolumn{4}{c}{ Liver } & \multicolumn{5}{c}{ Kidney } \\
\cline { 2 - 11 } Treatments & \multicolumn{3}{c}{ Scores of Lesions } & & \multicolumn{5}{c}{ Scores of Lesions } \\
\cline { 2 - 11 } & 0 & 2 & 3 & 4 & Mean & 0 & 1 & 2 & 3 & Mean \\
\hline T1 & 0 & 0 & 0 & 0 & 0 & 0 & 0 & 0 & 0 & 0 \\
T2 & 0 & $2 / 10$ & $2 / 10$ & $6 / 10$ & $2.4(++)$ & 0 & $3 / 10$ & $6 / 10$ & $1 / 10$ & $1.8(+)$ \\
T3 & 0 & 0 & 0 & 0 & 0 & 0 & 0 & 0 & 0 & 0 \\
T4 & 0 & $7 / 10$ & $2 / 10$ & $1 / 10$ & $1.4(+)$ & $4 / 10$ & $4 / 10$ & $2 / 10$ & $0 / 10$ & $1( \pm)$ \\
\hline
\end{tabular}

*Mean 10 birds, **T1 (0 ppm AF and no ST); T2 (2.5 ppm AF and no ST); T3 (0 ppm AF and 0.5 ml/1 ST); T4 (2.5 ppm AF and $0.5 \mathrm{ml} / 1 \mathrm{ST}),{ }^{* * *}$ The values represent the number of chicks showing changes/number of chicks examined in each treatment group. Severity of the lesions: $(-)=$ no lesions; $( \pm)=$ mild lesion; $(+)=$ moderate lesion; $(++)=$ sever lesion.

Table 3: Effect of Aflatoxin and Synertox ${ }^{\circledR}$ on relative weight of lymphoid organs of broiler chicks at 42 days of age*.

\begin{tabular}{lccccc}
\hline \multirow{2}{*}{ Treatments } & AF & Synertox $($ in water) & \multicolumn{2}{c}{ Relative organs weight $(\mathrm{g} / 100 \mathrm{~g}$ body weight) } \\
\cline { 4 - 6 } & (in feed) $\mathrm{ppm}$ & $\mathrm{ml} / \mathrm{L}$ & Thymus & Bursa of Fabricius & Spleen \\
\hline T1** & 0 & 0 & $0.13 \pm 0.03 \mathrm{a}$ & $0.30 \pm 0.07 \mathrm{a}$ & $0.18 \pm 0.05 \mathrm{a}^{* * *}$ \\
$\mathrm{~T} 2$ & 2.5 & 0 & $0.08 \pm 0.19 \mathrm{c}$ & $0.24 \pm 0.04 \mathrm{~b}$ & $0.25 \pm 0.01 \mathrm{~b}$ \\
$\mathrm{~T} 3$ & 0 & 0.5 & $0.12 \pm 0.03 \mathrm{a}$ & $0.31 \pm 0.08 \mathrm{a}$ & $0.18 \pm 0.02 \mathrm{a}$ \\
$\mathrm{T} 4$ & 2.5 & 0.5 & $0.10 \pm 0.05 \mathrm{~b}$ & $0.27 \pm 0.06 \mathrm{a}$ & $0.19 \pm 0.04 \mathrm{a}$ \\
\hline
\end{tabular}

*Mean \pm SE for 5 birds, ${ }^{* * T} 1$ (0 ppm AF and no ST); T2 (2.5 ppm AF and no ST); T3 (0 ppm AF and 0.5 ml/1 ST); T4 (2.5 ppm AF and $0.5 \mathrm{ml} / 1 \mathrm{ST}),{ }^{* * *}$ Means with same superscripts within a column do not differ from each other $(\mathrm{P}>0.05)$.

\section{Discussion}

Detoxifying agents and adsorbents are added to the manufactured poultry feed to prevent or minimize its toxic effect where we have no sufficient laboratory capability to confirm the purchase of ingredients free of mycotoxins. In addition, proper storage of ingredients, and feed processing, shipping and handling procedures are necessary to minimize mycotoxin formation $(20,21)$.

In this study, the reduction in growth rate of broiler chicks, is in agreement with other studies when birds were exposed to dietary AF (400 ppb,750 ppb) This could be attributed to reduced protein and energy utilization (22) which impaired nutrient absorption and reduced pancreatic digestive enzyme production (23) and consequently reduced appetite (24). This reduction in body weight is dose dependent (25). Similarly, significant depressions in body weight gain were also recorded in broilers given diets containing 1 and $2 \mathrm{mg} / \mathrm{kg}$ of AF (1000 to $2000 \mathrm{ppb}$ ) at 4 and 7 weeks of age and in a dose-dependent manner (26). With the line of our results, reduced feed intake and poor feed efficiency in broilers has also been reported in birds fed diets containing AF at 2, 4 and 6 weeks of age when level of dietary AF was higher than $100 \mathrm{ppb}$ (27).

These authors have suggested that the reduced appetite during aflatoxicosis could be due to impaired liver metabolism caused by the liver damage, as seen in our study by the significant increase in the liver score lesion
(Table 2 and Figure 3). It is likely that broiler chicks may highly respond to AF in diet as their physiological needs and capacity to absorb is higher compared to older birds. Gabal and Azzam (28), suggested that prolonged administration of AF at the low levels may cause relevant lesions in liver and renal tissues. Moreover, the metabolism of broilers seems to be more adapted to high concentrations of aflatoxin in the feed when administered to $42 \mathrm{~d}$ of age, when compared with data reported from similar experiments conducted with broilers aging 1 to $21 \mathrm{~d}$ and with other species such as turkey poults (29).

The sensitivity of the immune system to mycotoxininduced immunosuppression arises from the vulnerability of the continually proliferating and differentiating cells that participate in immune mediated activities and regulate the complex communication network between cellular and humeral components (30). Aflatoxin are reported to inhibits the histological development and functional maturation of lymphoid organs (31).Morphological evidence to explain the immunosuppressive effects of AF (2.500 ppm) was documented by (32) in broiler chickens after 21 days of feeding and the major signs were reduction in the weights of lymphoid organs including bursa of Fabricius, spleen and thymus. Similarly, (33) reported a significant decrease in the relative weight of the bursa of Fabricius when birds were exposed to diets having $2 \mathrm{ppm}$ AF. Similar reduction in bursal relative weight and moderate histopathological changes have been reported in broilers (34), when birds 
were fed diets having various levels of AF (100 to 500 $\mathrm{ppb})$.

In addition, vacuolation of liver cells and cellular depletion in the follicle medulla of the bursa Fabricii has been reported to be produced as an indication of aflatoxicosis by feeding lower levels of AF (100 ppb) over a long-term period of 42 days (35). The present study coincide with the significant difference $(\mathrm{P}>0.05)$ in lymphoid organs between different treatment groups (Table 3).

Means of antibody titre (ELISA) against Newcastle disease (ND) showed differences $(\mathrm{P}>0.05)$ between treatments when analysed at 42 day of the trial (Figures 58). The presence of AF in the feed is reported to decrease vicinal immunity and may therefore lead to the occurrence of disease even in properly vaccinated flocks (1). Aflatoxins have been associated to have immunosuppressive effect due to direct inhibition of protein synthesis, including those with specific functions such as immunoglobulin's IgG, IgA, inhibition of migration of macrophages, interference with the haemolytic activity complement, reduction in the number of lymphocytes through its toxic effect on the Bursa of Fabricius and impairment of cytokines formation by lymphocytes (36). In present study, significant difference $(\mathrm{P}>0.05)$ in ELISA titres was observed when treatment with AF (treatment 2) was compared with all other treatment groups suggests that birds exposed to $2.5 \mathrm{ppm} \mathrm{AF}$ in diet did show signs of immunosuppression.

In this study dietary $\mathrm{AF}$ at a rate of $2.5 \mathrm{ppm} \mathrm{AF}$ could cause vaccine failure as indicated by the significant reduction $(\mathrm{P}<0.05)$ of antibody titres against Newcastle disease vaccine, which agreed with the results of other investigators who fed broilers diets containing 2 to $3 \mathrm{ppm}$ AF (37). Similarly, (38) reported that even low levels of dietary AF (200 ppb) can cause reduction in antibody titres to vaccines for Newcastle disease, infectious bronchitis, and infectious bursal disease in layers fed for 40 weeks. This report is considered as the first one treating $\mathrm{AF}$ detoxification by Synertox ${ }^{\circledR}$. Anyhow, Synertox is a probiotic containing enzymes, organic acids and yeast extract which is easily dissolved in water, giving it superiority over other adsorbents because chicks continue to drink water in spite of their reduction in feed consumption during aflatoxicosis. The counteracting effect of AF by Synertox ${ }^{\circledR}$ on various parameters, could be attributed to the excellent content of organic acids and their salts, essential micronutrients and the extract of L- form microorganisms, which plays an important role as a chelating agent in the sequestration of the mycotoxin through the gastrointestinal tract, preventing them from absorption, and so help in getting rid of these toxins outside the body. Adsorption starts in the oral cavity during salivation and continues in stomach and gut.
So, the improved results in the treated flock can be attributed to the used antimycotoxin as reported by (39) who demonstrated that modified glucomannan (a cell wall derivative of yeast) had the ability to adsorb more than 75 $\%$ of the aflatoxin within 30 minutes after feeding the aflatoxin-contaminated diet

Synertox also has an important role in immunity stimulation. Moreover, the multiple acids contained in Synertox ${ }^{\circledR}$ increase the acidity in the GIT, favouring with the vitamin B complex and aspartic acid in the multiplication of the beneficial propiotic friendly lactic acid bacteria. Papain, which Synertox contains, in its own, as an anti inflammatory substance is also help in the protein digestion and, hence improve the immunity as immunmodulater besides protein digestion. The beneficial effect of Synertox ${ }^{\circledR}$ in ameliorating the negative effect of AF on ND antibody titres in this study is attributed to the excellent contents of this detoxifier.

In conclusion, our study pointed out that the administration of antimytoxins in water (here Synertox ${ }^{\circledR}$ ) could give high performance data as those adsorbents usually added to feed in alleviating Aflatoxicoisis in broilers.

\section{References}

1. Shotwell, O. L. 1991. In: 1. E. Smith and R. Henderson (eds.). Mycotoxins and Animal Foods. CRC Press: Boca Raton, FL.pp:325340.

2. Leeson S, Diaz G, Summers JD. Aflatoxins. In: Leeson, S., Diaz, G., Summers, J.D. (Eds.), Poultry Metabolic Disorders and Mycotoxins.1995 pp: 248-279. University Books, Canada, Ont.

3. Oguz H, Hadimli H.H., Kurtoglu, V., and Erganis, O. Evaluation of humoral immunity of broilers during chronic aflatoxin (50 and 100 $\mathrm{ppb}$ ) and clinoptilolite exposure. Revue de Medicine Veterinaire 2003; 154: 483-486.

4. Pramanik, A. K. and H. M. Bhattacharya. 1987. Diseases ofpoultryin three districts of West Bengal affecting the rural economy.Indian $\mathrm{J}$ vet Med 7:63-65.

5. Aflatoxins - Biochemistry and Molecular Biology Edited by Ramón Gerardo Guevara- González Published by InTech Janeza Trdine 9, 51000. Rijeka, Croatia Copyright (C) 2011 InTech.

6. Miazzo R, Rosa CA, De Queiroz Carvalho EC, Magnoli C, Chiacchiera SM, Palacio G, Saenz M, Kikot A, Basaldella E Dalcero A. Efficacy of synthetic zeolite to reduce the toxicity of aflatoxin in broiler chicks. Poultry Science, 2000; 79: 1-6.

7. Pasha, T.N., Mahmood, A., Khattak, F.M., Jabbar M.A, and. Khan. A.D. (2008). The Effect of feed supplementation with different sodium bentonite treatments on broiler performance. Turkish Journal of Veterinary and Animal Sciences, 2007; 32:245- 248

8. Oguz, H. and Kurtoglu, V. (2000). Effect of clinoptilolite on fattening performance of broilerchickens during experimental aflatoxicosis. British Poultry Science, 41: 512517.

9. Hyden, M. (2000): Protected acid additives. Feed Internat., 7:15-17.

10. Bedford, M. (2000): Removal of antibiotic growth promoters from poultry diets implications and strategies to minimize subsequent problems. World's Poult. Sci. J., 56:347-365.

11. Demir, E.; Sekeroglu, A. and Sarica, S.(2001): Comparisan of the effects of flavomycin, mannanoligasaccharide and probiotic addition to broiler diets. Brit. Poult. Sci., 42: 89-90. 
12. Piva, A. and Galvano, F. (1999): Nutritional approaches to reduce the impact of mycotoxins. Proc. Alltech. Ann. Symp., 15:381-399.

13. El-Nezami, H. H.; Mykkanen, P.; Kankaanpaa, S.; Salminen, and Ahokas; J. (2000):Ability of Lactobacillus and Propionibacterium strains to remove aflatoxin B1 from the chicken duodenum. J. Food. Prot., 63:549-552.

14. Amer, M.M. EL-Bayomi Kh. M Zeinab, M. S.A. G. Field Studies on Effect of Probiotic on Reproductivity of 51 Weeks Old Broiler Breeder Chickens Fed on Mycotoxins Contaminated Ration. Journal of American Science, 2011;7(4)

15. NRC (National Research Council).Nutrient requirement of poultry, $9^{\text {th }}$ ed. National Academy press, Washington D.C., USA, 1994.

16. Shotwell DL, Hessitine CW, Stubblefield RD, Sovenson WG. Production of aflatoxin on rice.Appl microbial,1966;14:425-428.

17. Thomas F, Eppley RM, Trucksess MW. Rapid Screening method for aflatoxin on rice.Appl Microbiol 1975;57:114-116.

18. Nagy E.Application of recombinant viruses in the prevention of Newcastle disease, Magy.Allat.Orv.Lapta,1999;121:239-242.

19. Bruning JL,Kintz BL. Computation handbook of statistics, scott foresman and Co. Glenview IIlinios,.1977;pp:18.

20. Dawson, K.A. (2001): The application of yeast and yeast derivatives in the poultry industry. Proc. Aust. Poult. Sci. Sympos. 13: 100-105.

21. Saif Y. M.; Barnes, H. J.; Fadly, A. M.; Glisson, J. R.and Swayne, D. E. (2003): Poultry Diseases, 11th Ed.,Iowa State Press, Iowa.

22. Dalvi RR, Ademoyero A A. Toxic effects of aflatoxin B1 in chickens given Feed contaminated with Aspergillus flavus and reduction of the toxicity by activated charcoal and some chemical agents. Avian Disease, 1984; 28: 61-69

23. Verma, J., B. K. Swain, and T. S. Johri. Effect of various levels of aflatoxin and ochratoxin $\mathrm{A}$ and combinations thereof on protein and energy utilisation in broilers. Journal of Science Food and Agriculture, 2002; 82:1412-1417.

24. Osborne DJ, Hamilton PB. Decreased pancreatic digestive enzymes during aflatoxicosis. Poultry Science, 1981; 60: 1818-1821.

25. Sharline KSB, Howarth BJ, Wyatt RD. Effect of dietary aflatoxin on reproductive chicks. Poultry Science, 1980; 72: 651-657.

26. Espada Y, Domingo M, Gomez J, Calvo MA. Pathological lesions following an experimental intoxication with aflatoxin B1 in broiler chickens. Research in Veterinary Science, 1992; 53: 275-279.

27. Beura CK, Johri TS, Sadagopan VR, Panda BK. Interaction of dietary protein level on dose response relationship during aflatoxicosis in commercial broilers. I. Physical responses livability and nutrient retention. Indian Journal of Poultry Science, 1993; 28: 170—177.
28. Gabal MA and Azzam A H. Interaction of aflatoxin in the feed and immunization against selected infectious diseases in poultry. II. Effect on one-day- old layer chicks simultaneously vaccinated against Newcastle disease, infectious bronchitis and infectious bursal disease', Avian Pathology, (1998). 27(3): 290 - 295

29. Pier, A.C., Richard, J.L. and Thurston, J.R. (1979). The influence of mycotoxins On resistance and immunity. In Interaction of Mycotoxins in Animal Production (pp. 96-117).Washington, DC: National Academy of Sciences

30. Pestka JJ, Bond y GS 1994: Immunotoxic effects of mycotoxins. In: Miller JD, Trenholm HL (Eds): Mycotoxins in Grain. Eagen Press, St Paul. pp. 339-358

31. Campbell, M.L., May, D., Huff, W.E. and Doer, J.A. (1988). Evaluation of Immunity of young broiler chickens during simultaneous aflatoxicosis and ochratoxicosis. PoultryScience, 62: 2138-2144

32. Celik I, Oguz H, Demet O, Donmez HH, Boydak M, Sur E. Efficacy of polyvinylpolypyrrolidone in reducing the immunotoxicity of aflatoxin in growin broilers. British Poultry Science, 2000; 41: 430-439

33. Dalvi RR, Ademoyero A A. Toxic effects of aflatoxin B1 in chickens given Feed contaminated with Aspergillus flavus and reduction of the toxicity by activated charcoal and some chemical agents. Avian Disease, 1984; 28: 61-69

34. Marquez RNM, Hernandez TR. Aflatoxin adsorbent capacity of two Mexican aluminosilicates in experimentally contaminated chick diet. Food Additives and Contaminants 1995; 12: 431-433.

35. Giambrone JJ, Diener UL, Davis ND, Panangala VS, Hoerr FJ. Effects of aflatoxin on young turkeys and broilers chickens. Poultry Science, $1985 ; 64,1678-1684$.

36. Ibrahim IK, Shareef AM, Al-Joubory KMT. Ameliorative effects of sodium bentonite on phagocytosis and Newcastle disease antibody formation in broiler moor heir chickens during aflatoxicosis. Research in Veterinary Science, 2000; 69: 119-122.

37. Mohiuddin SM, Reddy VM. Immunosuppressive effect of aflatoxin in bursectomised chicks against Ranikhet disease vaccine. Indian Journal of Animal Sciences, 1993; 63: 279-280.

38. Johri TS, Majumdar S. Effect of methionine, choline, BHT, supplemented aflatoxic diets, Proc. XIII National Symposium of Indian Poultry Science., Assoc, held at Bombay on 20-22 Dec., 1990.

39. Murthy T. N. K. and Devegowda, G. (2004): Efficacy of modified glucomannan $\left(\right.$ mycosorb $\left.{ }^{\circledR}\right)$ to adsorb aflatoxin b1 in gut conditions of broiler chickens. Proc of XXII WPC Sc. June 8-13, Istanbul. 